\title{
The Analysis Of Material Presentation And Assessment Of Thematic Learning At State 1 Primary School Sleman Yogyakarta
}

\author{
Hamruni* $^{*}$ dan Istiningsih ${ }^{* *}$ \\ "Lecturer at Faculty of Tarbiyah State Islamic University “Sunan Kalijaga” Yogyakarta email: sirzak233@yahoo.com \\ "Lecturer at Faculty of Tarbiyah State Islamic University “Sunan Kalijaga” Yogyakarta email: istiningsih81@ gmail.com
}

\begin{abstract}
Thematic-Integrative Learning Model is a fairly new learning of its existence. The model is applied in particular in conjunction with the elementary school, or more precisely in the frame of the curriculum of 2013. There are two things that are quite crucial in this learning models include the presentation of material and assessment. In general the presentation of the material can be described through the steps. First, mapping the basic competencies and scope of subjects in a net. In each sub theme subdivided form the six learning, one study submitted for one day. Second, mapping learning indicators. Description of activities in the form of interest, media, and tools, as well as the operational measures. For example it can be described in one semester class I consists of four themes. Each theme consists of four sub-themes. Each sub-theme is decomposed into six learning, one allotted for a day of learning. In the context of the assessment on an integrative model of thematic learning outline contained among other valuation techniques. Test (written, ral and practical or performance). Techniques of observation carried out during or beyond the learning and teaching. Mechanical giving assignments to individuals or groups that can be shaped and household chores or projects. In practice forms of assessment are used there are three such tests in the form of a written test and performance, observation and portfolios.
\end{abstract}

Key Word: Thematic-Integrative, material, assessment

\section{INTRODUCTION}

Thematic learning, particulary on Primary Education in Indonesia is not a new matter. Learning which utilize thematic model has been started in the past Curriculum 2014. The difference is in Competence-Based Curriculum, thematic is only directed for low grade, however in Curriculum 2013, thematic is prevailed for all grades. In Primary School context, low grades are Grade 1, 2 and 3. While Upper Grade are Grade 3, Five, and Six. Integrated Thematic Instruction (ITI) is developed in the beginning of 1970s. Thematic learning is believed as one of highly effective teaching models because it is able to cover and touch emotional, phisical, and academic dimensions in the classroom or school environment integratively. The Thematic Learning Models has also been proven empirically to enhance learning and increase long-term memory capabilities of learners for long. Integrated thematic learning is often called as integrated thematic instruction which is initially conceptualized in 1970s. This learning approach is developed for gifted and talented and smart children, learning extension program, and accelerated learners. Thematic learning is also applied in black Wednesbury people who live in slum and narrow residence in order to dig their creativity. Thematic learning model has qualitative diffference to another because their characteristic is to guide learners to reach higher level of thinking by optimizing multiple thinking skills, an inovative process for the development of attitude, skill and knowledge dimension. Thematic model learning is a learning which integrate some lessons in certain themes. Thus, it is not provided in form of lesson, but in themes.

Presenting material from some lessons which is integrated into one is not easy regarding different cross competence and knowledge chacacteristics so that it requires special competence to overcome it well. Also in thematic learning assessment. Making assessment in thematic learning is not easy as making assessment in learning using lesson approach because one-sheet questions cover many different competence of knowledge. In order to correct students' worksheet on thematic model will takes so much time because teacher should sort and choose and categorize which is included in math and which one is not. It is because the report is not in form of thematic but lesson nomenclature. This demands the reseach is implemented. As outlined, this research deeply digs how the material presentation in thematic learning, asssessment implementation in the learning and strenghts and weaknesses of integrative thematic model learning are. This research is conducted in State Primary School I Sleman Regency Yogyakarta. The school becomes parents' choice to educate their children. By educating them at this school, the output will obtain a priority to be accepted in State Junior High School I 
Godean as favorite Junior High School in Sleman Regency. ${ }^{1}$ The school always reaches the third rank, which means that one day it reaches the second and third sometimes. Also, in order to register in State Junior High School I Godean, student have to get at least 29 of the three tested lesson in their National Examination. ${ }^{2}$ It is applied from registrars who come from Primary School other than State Primary School I Sleman. However, if the registrars come from State Primary School I Sleman, they obtain dispensation if their National Exammination score is minimum 28. Furthermore, output from State I Primary School Godean is given quota at least $20 \%$ to be acceptable as students of State 1 Junior High School Godean. It means that if they study at State Primary School I Sleman, students will have bigger opportunity to be accepted as a part of outstanding school in Sleman Regency.

Besides being output priority State Primary School I Sleman can be accepted in favorite school. It also has many achievements so that it is pointed as one of school models that applies curriculum 2013 which within implements thematic learning. ${ }^{3}$ Thematic learning at Primary School is one of consequence forms of curriculum 2013 implementation policy. It is as presented by Education Minister M.Nuh that the learning process for Primary School level uses thematic approach. ${ }^{4}$

\section{THEORETICAL REVIEW}

There are some natural thematic definition, one of them as in The Oxford Pocket Dictionary of Current English $^{5}$ which defines thematic as having or relating to subjects or a particular subject: the orientation of this anthology is essentially thematic. Thematic definition in Oxford Dictionary signs that thematic concerning the subject or a part of subject, while in Indonesian Dictionary (Kamus Besar Bahasa Indonesia), thematic is defined as matters concerning theme. ${ }^{6}$ While, learning is interaction process between learners and environment, so that behavioral change to better direction. ${ }^{7}$ According to Jackson, learning is a systematic effort in organizing learning environment in order to grow and develop learners' study. ${ }^{8}$ Therefore, thematic learning can be defined as an effort to organize learning environment systematically in order that interaction process between teacher and learners to perform behavior change to better behavior by constructing material in form of themes.

Akhmad Sudrajat states that thematic learning is an integrated learning which uses theme to relate some lesson so that it gives meaningful experience towards learners. ${ }^{9}$ Carole Cook Freeman and Harris J. Sokoloff in the research creates thematic curriculum theory. Carol and Haris' study entitled "Pet and Me" which is published in 1995, furthermore, it should popularize the term of thematic learning. This unit is designed through cooperation among students which is directed to preschool and primary school students to the 5th level. ${ }^{10}$ Data analysis is collected during the development and unit field test supports curriculum dynamic display which challenges policy makers to rethink the policy which is started from curriculum view as static list "fact" learnt or "topic" that should be mastered.

The reflection is caused differentiation of three different constructions: (1) fact and information, (2) topic, and (3) theme. Each of the three constructions plays different role in children learning. Focus fact on basic information and ideas which are defined narrowly is understood as discrete item. The topic gives fact and information context, and present the way of organizing information into experience class as recignized by scientists in traditional discipline. The theme is defined as broad existential questions exceed discipline, enable learners to integrate information and topic into various individuals' experience. The three elements are important in thematic curriculum. ${ }^{11}$ Learning which departs from thematic curriculum theory is learning which positions teacher and learners equally as learners. ${ }^{12}$

\footnotetext{
${ }^{2}$ Iksan, Student of State Junior High School I Godean Sleman. Interview 4 November 2015

${ }^{3}$ Narto, Student's Guardian of State Primary School I Sleman. Interview 3 November 2015

${ }^{4}$ M. Nuh, Rasionalisasi Kurikulum 2013. In http://www.Kemendikbud.go.id 1 November 2015

${ }^{5}$ The Oxford Pocket Dictionary of Current English, 2009. In http://www.encyclopedia.com pada 10 September

${ }^{6}$ Kamus Besar Bahasa Indonesia, 2007. In http://kamusbahasaindonesia.org/tematik, pada 15 September 2014

${ }^{7}$ E. Mulyasa, Kurikulum Tingkat Satuan Pendidikan, (Bandung: Rosda Karya, 2006), p. 245.

${ }^{8}$ Rusman, Model-Model Pembelajaran: Mengembangkan Profesionalisme Guru..., p. 252.

${ }^{9}$ Akhmad Sudrajat, Pembelajaran Tematik, Artikel Online, 2014. in http://akhmadsudrajat. wordpress.com/pembelajaran tematik di kelas awal sekolah dasar

${ }^{10}$ Carole Cook Freeman dan Harris J. Sokoloff, Toward a Theory of Thematic Curricula: Constructing New Learning Environments for Teachers \& Learners, A peer-reviewed scholarly electronic journal Volume 3 Number 14 September 1995. In http://www.upenn.edu/gse/CSSC

${ }^{11}$ Ibid.

${ }^{12}$ Ibid.
} 2015

${ }^{1}$ Esti Widya Kusuma, Alumni of State Junior High School I Godean Sleman. Interview 1 November 
It is different to thematic learning in Indonesia. It is not implemented based on thematic curriculum but Curriculum 2013. Therefore, the existing curriculum is in form of lessons collection so that it should be integrated in form of themes. It demands teacher's creativity in thematizing in although it has obtained learning sources in form of lesson textbooks which are produced by educational and cultural ministerial using thematic approach. However, partcularly Islamic Education has not obtained books or thematic learning model which is integrated with another lesson that becomes guideline for teachers in implemening thematic learning.

\section{Thematic Learning Elements}

Thematic Learning Implementation demands teacher's competence in transforming learning material in the classroom. Since teacher should understand which material is taught and how it is applied in classroom learning envionment. Since The Thematic Learning Model is brain friendly, he/she should be able to identify relevant environmental elements and can be optimized when he/she interacts with learners during the learning process. There are ten relevant elements that should be improved by teachers. ${ }^{13}$

a. Reducing absence level or additional value of thinking reflectively.

b. Enriching experimental sensory in attitude, skill and knowledge field.

c. Presenting content or substance of meaningful learning

d. Environment which enriches learning.

e. Movement to trigger Movement to Enhance Learning

f. Opening selections

g. Time optimization accurately

h. Collaboration

i. Immediate Feedback

j. Completeness or application

\section{The Benefit of Thematic Approach ${ }^{14}$}

a. Comfortable and fun class atmosphere. Class atmosphere enables all people within to have willingness to take risk together. For example, answering incorrect questions without offending learners' feeling. Daily work procedures ensure that all schedules are predicted and assure that learners feel safe when they are in and out of class. Life skill is recognized, discussed and practiced by learners with correct interaction and fun feeling in classroom community.

b. Utilizing group of cooperation, collaboration, study group, and conflict resolution which encourages learners to solve social problem and respect each other

c. Optimizing learning environment as brain-friendly classroom. Learning activity which involves learning subject directly optimizes all learning sources and give learners with opportunities to explore material widely.

d. Learners correctly and ontime are able to process information. The process does not only touch quantity and quality dimension,but also explore new concepts and assist learners to develop their knowledge readily.

e. Classroom learning process encouragelrstnrtd in brain-friendly format.

f. Learning material presented by the teacher is applicable by learners in their daily life.

g. Learners who experience retardation to complete learning program can be assisted by teacher by giving special guidance and implementing completed learning principals.

h. Brain-friendly learning program enable teacher to implement learning completeness by implementing variations of assessment method.

\section{Thematic Learning Steps ${ }^{15}$}

The important point of the thematic learning is material presentation. Material presentation of thematic learning is done through stages such as:

a. Determining the theme. Theme can be applied by teacher and can be applied together with learners. The theme can be applied by teacher and once applied by learners. It is applied integrated thematically, can be done by the teacher and may be agreed by learners.

b. Integrating the prevailed theme and curriculum. On this stage, the teacher should be able to design learning theme by integrating it in line with curriculum demand by prioritizing attitude, knowledge and skill dimension.

\footnotetext{
${ }^{13}$ Anonim, Pembelajaran Tematik Sekolah Dasar, Materi Sosialisasi Kurikulum 2013 Kementerian Pendidikan dan Kebudayaan, 2013

${ }^{14} \mathrm{Ibid}$.

${ }^{15} \mathrm{Ibid}$. 
c. Designing learning plan and coculicular activities. This stage covers extracurricular sources and activities organizing in order to demonstrate the theme. For example, through tourism study, museum visit etc.

d. Group activity and discussion. This activity enables learners to participate and reach variaous perspective of the theme. It helps teachers and learners in explorating subject.

\section{Thematic Learning Principals}

a. Theme should not be too wide and can be easily used to combine many study fields.

b. Selected theme provides provisions for learners to continue study.

c. The theme is fit with the level of learners development.

d. The theme should be able to facilitate most of children's interest.

e. The theme should consider authentic events occur in learning time gap.

f. The selected theme should be appropriate with the prevailed curriculum.

g. The selected theme shoould be appropriate with learning souce availability.

\section{Thematic Learning Models ${ }^{16}$}

Integrated thematic learning can be implemented with various models. According to Robin Fogarty

(1991) there are ten Thematic Learning models, such as:

a. Fragmented Model. It is implemented with limited combination of one lesson. For example, Indonesian Lesson on scrutinizing, speaking, reading and writing materials are combined in language skill learning material.

b. Connected Model. This model is implemented based on an asumption that learning points are covered in certain lesson chief. Learning points such as vocabulary, structure, reading and writing are covered in language and literature lesson.

c. Nested model. It is implemented by combining various skill concept mastery forms through learning activity. For example, during certain times, teacher focusses learning activity on word form understanding, word interpretation and expression or idiom which target skill creation in developing imagination and logical thinking capacity, determining characteristics of words form and meaning in poem, making expression and writing a poem.

d. Sequenced Model. It combines topics between different lessons paralelly. The content of story in historical romance, for example : paralel discussion topic (similar time) can be combined with historical matter of national struggle, characteristics of social life on certain period, or topics concerning word meaning change.

e. Shared/Participative Model. It is the combination of learning caused by overlapping concept or idea on two lessons or more. Learning points on civic education can be overlapping with State Lesson, National Struggle History etc.

f. Webbed model. This model departs from thematic approach as basic refferent of learninng material and activity. The theme made can bind learning activities, both in certain lesson or inter lesson.

g. Threaded nidek. This model combines skill forms. For example: predicting and estimating in math, prediction towards events, anticipation towards story etc. This model form focusses on meta curriculum.

h. Immersed model. This model is designed to help learners to sort and combine various experiences and knowledge related to the use field. Learning activity is directed to facilitate experience exchange and the utilization of each experience.

i. Networked model. This model is a learning combination model which assumes the conception change possibilitym, problem solving form, or new skill form demand after learners perform field study in different situation, condition or context.

j. Integrated model. This model is a combination of a number of topic started from different lesson, but the essence is similar in certain topic. Evidence topic which is previously included in math, Bahasa Indonesia, Natural and Social Science so that it cauese overload curriculum are included in certain lesson, for example Natural Science.

\section{Assessment and Research Types}

In order to implement a good authentic assessment, a teacher should clearly understand the objectives that will be reached. Therefore, a teacher should ask him/herself, especially concerning (1) which attitude, skill and knowledge that will be assessed; (2) assessment focus will be perfomed, for example concerning attitude,

${ }^{16}$ Anonim, Pembelajaran Tematik Sekolah Dasar, Materi Sosialisasi Kurikulum 2013 Kementerian Pendidikan dan Kebudayaan, 2013.

DOI: $10.9790 / 0837-2205092337 \quad$ www.iosrjournals.org $\quad 26 \mid$ Page


skill and knowledge; and (3) which knowledge level that will be assessed such as logic, memory or process. Some types of assessment are presented as follow:

a. Performance Assessment

Authentic assessement should involve learners' participation, especially in the process and aspects that will be assessed. Teachers are able to perform it by asking learners to mention elements of project/task that wiil be used by them to determine the resolution criteria. By using this information, teachers are able to give feedback towards learners' performance, both in narrative or class report. There are some different methods to record performance-based assessment result:

b. Checklist. It is utilized to know whether certain elements of indicators or subindicators emerge or not in an occurence or action.

c. Anecdotal/narative records. Teachers utilize it to write narrative records on what will be done by each learning during the action performance. Of the record, teachers are able to determine how well learners fullfill the determined standard.

d. Rating scale is usually used by using numeric scale and its predicates. Such as : $5=$ very good, $4=$ good, 3 = sufficient, 2 = lack, 1 = very lack.

e. Memory approach. It is utilized by teacher by observing learners when they are performing something with or without taking a note. A teacher utilizes information which comes from her/his memory to detemine whether learners have been successful or not

Performance assessment requires special considerations. First, performance steps should be done by learners to show a real performance towards a matter or some certain competence types. Second, accuracy and completeness of assessed performance aspects. Third, special abilties required by learners to complete learning tasks. Fourth, the main focus of performance that will be assessed, especially observed essential indicator. Fifth, the sequence of capability or skill of learners that will be observed.

Observation of learners' performance should be done in various contexts to determine certain competence achievement. In order to learners' assess language skill of speaking skill aspect, for example the teacher observes it on the similar context, such as giving speech, discussing, story telling, and interviewing. Thus it will be obtained a totality of intended speaking skill. In order to observe the performance, learners are able to use instruments, such as attitude assessment, behavior observation, direct or personal questions.

Self-assessment is included in performance assessment family. Self-assessment is an assessment technique in which learners are asked to assess themselves concerning the status, process, and competence achievement level which are learnt in cetain lesson. Self-assessment technique can be used to measure cognitive, affective and psychomotoric competence. Self-assessment technique has some positive benefits. First, grow learners' self confidence. Second, learners realize their strengths and weakness. Third, encourage, habituate, and train learners to behave honestly. Fourth, grow personal spirit to develop.

f. Project Assessment

Project assessment is an assessment activity towards a task that should be completed by learners according to certain period. The completion is investigation as performed by learners, started from planning, data collection, organizing, processing, analysis, and data presentation. Therefore, project assessment touches and applies understanding aspect,investigation, etc. During the process of learning project, learners have opportunities to apply attitude, skill and knowledge. Therefore, at least there are three things that needs teacher's special attention in each project assessment.

1) Learners' skill in selecting topic, finding and collecting data, processing and analyzing, giving meaning or information which is obtained, and writing a report.

2) Appropriateness or relevance between learning material and attitude development, skill and knowledge requred by learners.

3) Originality of a learning project performed or resulted by learners.

Project assessment is foccussed on project planning, execution, and products. Regarding this matter, the series of activities that should be performed by teacher involves design arrangement and assessment instrument, data collection and analysis and report preparation. Project assessment can use checklist instrument, assessment scale, or narrative. Assessment report can be in form of poster or writing.

End product of a project is likely require special assessment. Product assessment of a project is intended to assess quality and form of end result holistically and analytically. The intended product assessment involves assessment on learners' competence to produce a product, such as food, clothes, 
artwork (painting, image, sculpture, etc), stuff made of wood, paper, leather, ceramic, rubber, plastic, and metal. Analytical assessment refers to all criteria that should be fullfilled to create certain product. Holistic assessment refers to appreciation or impression as a whole on resulted product.

g. Portfolio Assessment

Portfolio assessment is an assessment of a group of artefacts that indicate development and are respected as work result of real world. Portfolio assessment departs from individual learners' work result or is produces in group, requires learners' reflection and is evaluated based on dimension.

Portfolio assessment is continous assessment which is based on a group of information which indicates learners' competence development in certain period. The information can be in form of learners' work resulted from learning process which is considered as the best, test result (not score), or other relevant information with attitude, skill, and knowledge demanded by certain topic or lesson. The focus of portfolio assessment is a group of individual learners' works or groupwork in certain learning period. The assessment is performed especially by the teacher, although learners can also do so.

Through portfolio assessment, the teacher will recognize learners' learning development or progress. For example, their work in organizing and composing a writing, poem, letter, musical composition, picture, photo, painting, book or literature review, research report, synopsis, etc. On behalf of the assessment base, teacher and/ or learners are able to revise as the learning demand. Portfolio assessment is perormed by using steps as follow:

1) Briefly, teacher explains the essence of portfolilo assessment.

2) Teacher or teacher and learners determine portfolio types that will made.

3) Learners, both individual or in group, independently or under teacher's advise, arrange learning portfolio.

4) Teacher collects and save learners' portfolio in an appropriate place, accompanied by the note of collection date.

5) Teacher assesses learners' portfolio with certain criteria.

6) If it is possible, teacher and learners discuss resulted portfolio document together.

7) Teacher provides feedback towards learners on the portfolio assessment result.

8) Written Assessment

Eventhough the conception of authentic assessment raises from disatisfaction towards written test which is normally executed in previous era, written assessment on learning result is normally performed. Selecting and supplying answers. Selecting answers consist of multiple choices, True or false choice, yes or no, matching, and cause-effect. Supplying answers consist of filling the blank or completing, brief or short answer, and esssay.

Written test which is in form of essay demands learners to memorize, comprehend, organize, apply, analyze, syntesize, evaluate,etc on the material that has been learnt. Written test which is in form of essay should be comprehensive, so that it describes learners' attitude, skill and knowledge area. On the essay test, learners have opportunity to give their own answer which is different to their peers, however, it still opens the opportunity to have similar score. For example, certain learners see poverty phenomenon from the work lazziness point of view, low skill or natural source scarcity. Each point of view will create different answer, but it is opened towards similar truth, as long as the analysis is correct. Essay test usually demands two answer pattern types, which are extended or restricted response. It depends on the question weight given by the teacher. Such test provides teacher with opportunity to assess learners' study result on higher or complex level.

1.

\section{RESEARCH RESULT AND DISCUSSION}

\section{Thematic Learning Material Presentation}

Material scope and graduate competence standard is important to be recognized firstly. Graduates competence standard involves core competence 1, which is spiritual attitude; core competence 2, social attitude; core competence 3, knowledge; and core competence 4, skill. Of the four core competences, they are constructed into themes completely wich within is represented by Basic Competence (BC). The material packaging in form of themes as the trasndiciplinary learning process in which it relates material as the context of learners and their environment and uses integrated approach in form of multidisciplinary and transdisciplinary learning so that there are no overlap among the lessons. Therefore, effective and efficient learning absorption is obtained.

Learning material in Curriculum 2013 which utilizes thematic model is based on activities. Learning material in form of activities designed to be performed by learners. The material design is aimed to be performed by learners together with learners to reach certain competence. The material is not a memorization material, but activity practice performed both independently or in group. As the characteristics of curriculum 2013, learners are asked to read other available source. Teacher is able to enrich creation in form of another 
activity which is relevant and sourced from natural, social, and cultural environment. The material is scientific or uses scientific approach in which it involves logical activity.

Learning activity is developed in form of theme network so that it gives image on a theme which covers some basic competences and indicators of various lessons. In order to see the score of learning material in Grade I State I Primary School Godean, we should see graduate competence standard and core competence. Graducate Competence Standard and Core Competence of Grade I involves three domains, among them are attitude, knowledge and skill. ${ }^{17}$

In general, material presentation can be drawn through the following steps: First, mapping basic competence and scope of lessons in networks. Theme: Self, sub-theme: Aku dan Teman Baru. Each subtheme is divided into six learnings. One learning is presented in one day. Second, mapping learning indicator in subtheme of Aku dan Teman Baru as included in which lesson and indicator.Third, activity elaboration in form of objective, media, and instruments and activity steps. For example it can be described on Grade I Semester I that consists of four subthemes. Each sub theme is elaborated into six lessons, one lesson for one day.

Material presentation will be illustrated in details as the elaboration line as drawn previously. The steps are as follow ${ }^{18}$ :

a. Mapping basic competence 1 and 2 for sub theme Bermain di Lingkungan Rumah. The mapping descriptions among them are by making networks. Each network consist of diferent lesson.. First, Bahasa Indonesia lesson involves competences as follow: 1.1. receive The God Almighty grace in form of Bahasa Indonesia which is known as unity language and learning facility in the local language variety,, 2.1. have self confidence and responsibility feeling towards the existence of family members and documents owned by family through the use of bahasa indonesia and or another/. Second, Sport and Health Psysical Education: 1:1 respect the body and all movement sets and its ability as God's grace. 2.2. Responsible towards self-, other people and environmental security, and the use of learning facility, 2.3. respect individual characteristic difference in doing various psysical activities, 2.1. indicate precise and careful, honest and orderly in following rules, care, time discipline and uneasy to give $\mathrm{u} p$ in doing their task. Fourth, Cultural Art and P. 1.1. Enjoying natural beauty and art work as one of God's power sign, 2.2. showing curiousity to know the environment as an idea source in creating an art. Fifht, Civiv Education. 1.1. Accepting individual characteristics variety in religious and ethnical life, pysichal and psychological charactersitics as The God Almighty's grace at home or school environment, 2.1. Indicating tolerance, affection, honesty, discipline, responsibility, politeness, care and self confidence behaviors in interacting with family, friends and teacher as the manifestation of Pancasila moral.

b. The next step is by determining competence standard 3 and 4 . Competence standard 3 and 4 are elaborated as in competence standard 1 and 2 which are elaborated in five lessons such as: Mathematics, Health and Sport Physical Education, SBDP, Bahasa Indonesia (Indonesian Language), and Civic Education.

After mapping competence standard, it is elaborated in more detail into Learning Scope for Subtheme Bermain di Lingkungan Rumah (Playing at House Environment). The elaboration of learning scope is categorized in developed learning activity and skill. In more detail, it is explained in the follwong table:

\begin{tabular}{|c|c|c|}
\hline No & earning Activity & Developed Compe \\
\hline 1. & $\begin{array}{l}\text { 1. Identifying various playing activities } \\
\text { at home. } \\
\text { 2. Identifying each individual's } \\
\text { characteristics at home. } \\
\text { 3. Expressive drawing by using various } \\
\text { media in house environment. } \\
\text { 4. Determining syllables which have not } \\
\text { been recognized from mathematics } \\
\text { sentence concerning summation. }\end{array}$ & $\begin{array}{l}\text { Attitudes : accurate, confident, and responsible. } \\
\text { Knowledges: } \\
\text { 1. Completing sentences based on conversation } \\
\text { text. } \\
\text { 2. Telling variety with different family members } \\
\text { who have different gender, hobby and } \\
\text { character. } \\
\text { 3. Determining sillables that have not been } \\
\text { recignized from mathematics sentence } \\
\text { conerning summation. } \\
\text { Skills: } \\
\text { 1. Reading conversation text. } \\
\text { 2. Taking a note of main points concerning to } \\
\text { play in house environment. } \\
\text { 3. Writing a narrative story. } \\
\text { 4. Expressive drawing }\end{array}$ \\
\hline
\end{tabular}

${ }^{17}$ Kemendikbud RI, Tema 2 Diriku, Buku Tematik Terpadu Kurikulum 2013, Buku Guru SD/MI Kelas I, (Jakarta: Kemendikbud RI, 2015), p. xi.

${ }^{18}$ Kemendikbud RI, Bermain di Lingkunganku, Buku Tematik Terpadu Kurikulum 2013 Buku Guru SD/MI Kelas II, (Jakarta: Kemendikbud RI, 2014), p. 1-7.

DOI: 10.9790/0837-2205092337 $\quad$ www.iosrjournals.org $\quad 29 \mid$ Page




\begin{tabular}{|c|c|c|}
\hline & & 5. Reasoning of truth value of a similarity. \\
\hline 2. & $\begin{array}{l}\text { 1. Doing various locomotoric basic } \\
\text { movements in simple games. } \\
\text { 2. Determining syllables which have not } \\
\text { been recognized from mathematics } \\
\text { sentence concerning summation.. } \\
\text { 3. Telling various stories on house } \\
\text { activities. } \\
\text { 4. Explaining family member variety } \\
\text { based on characteristics they posses. }\end{array}$ & $\begin{array}{l}\text { Attitudes : accurate, confident, and responsible. } \\
\text { Knowledges: } \\
\text { 1. Explaining the meaning of individual's owned } \\
\text { characteristics. } \\
\text { 2. Completing vaeriety at home. } \\
\text { 3. Determining syllables which have not been } \\
\text { recognized from mathematics sentence } \\
\text { concerning sum. } \\
\text { 4. Reading narrative text. } \\
\text { 5. Completing sentence which tells experience of } \\
\text { helping family to shop. } \\
\text { 6. Doing locomotoric basic movement activity } \\
\text { (walk, run, jump and throw). } \\
\text { 7. Arranging hotos, playing activities at home. } \\
\text { 8. Proposing steps of determinig syllables that } \\
\text { have not been known from matematic } \\
\text { sentence concerning summation. }\end{array}$ \\
\hline 3. & $\begin{array}{l}\text { 1. Determining syllables which have not } \\
\text { been recognized from mathematics } \\
\text { sentence concerning summation. } \\
\text { 2. Explaining various textures and } \\
\text { shapes. } \\
\text { 3. Telling activities in form of narrtive } \\
\text { text. }\end{array}$ & $\begin{array}{l}\text { Attitude: accurate, confident, and responsible. } \\
\text { Knowledges: } \\
\text { 1. Answering narrative text questions. } \\
\text { 2. Determining sillables that have not been } \\
\text { known from mathematic sentence conerning } \\
\text { summation. } \\
\text { Skills: } \\
\text { 1. Reading narrative text. } \\
\text { 2. Drawing expressive } \\
\text { 3. Telling playing activities in the environment. } \\
\text { 4. Proposing steps of determinig syllables that } \\
\text { have not been known from matematic } \\
\text { sentence concerning deduction. }\end{array}$ \\
\hline
\end{tabular}

c. The next step is by mapping Learning Indicator on Learning I . the example of Learning Indicator of subtheme Bermain Di Lingkungan Rumah. Bahasa Indonesia lesson: 3.2. To know simple narrative text on activity and playing in the environment with teacher's or friend's assistance in oral and writen Bahasa Indonesia that can be filled with local language vocabularies to help the underrstanding. 4.2. To model simple narrative text on activity and playing in the environment with teacher's or friend's assistance in oral and writen Bahasa Indonesia that can be filled with local language vocabularies to help the underrstanding. The indicator is 3.2.5 that identifies various playing activities in the surrounding/environment 3.2.8 note taking on main points of playing activity with certain topic. 4.2.2 to write simple narrative story on plaing activity on the surrounding using a good PSS. SBDP: 3.1. to know materials, instruments and techniques in making fine arts, 4.1. Draw expressing by processing line, color, shape and texture based on the enviromental observation result. The indicators are: 3.1.1. expressive drawing by using various media in the surrounding. Mathematics: 3.3. to know similarity of two expressions using concrete things, symbols or numbering summation / deduction to one number. 4.5. effectively solve real problems concerning summation, deduction, multiplication, division, time, weight, lenght, things weight and money, furthermore examine the answer reliability. Indicator 3.3.. Determine syllables that have been known from mathematics concerning summation (right part of division of 1 syllable, left part of division of 2 syllables). Civic Education: 3.3. Understand individual characteristics variations at home and school. 4.3. Interact with many friends in the environment of friend and school. Learning indicator: 3.3.1. Mention variations of family members based on gender. 3.3.2. Mention variation of family members based on gender. 4.3.1. Tell a story on variation of family members (who have different gender, hobbies and characters).

\section{Thematic Learning Assessment}

\section{a. Assessment Technique and Instrument}

Assessment is one of urgent activities in education world. Learning which is carried out in school institution should make assessment. The assessment is important and meaningful for teachers because by performing it, teachers obtain information on students who have and have not mastered the materials so that it 
requres a remedy. ${ }^{19}$ In doing the assessment, it needs an instrument which is furthermore called as assessment instrument by Arikunto ${ }^{20}$. In using the instrument, evaluator uses technique which is often called as assessment technique term. In general assessment techniques utilized in the thematic learning are, ${ }^{21}$ :

1) Test (written, oral, and practice or field practice)

2) Observation technique wich is carried out during the lesson or outside the lesson.

3) Task giving technique for individual or group can be in form of homework or project.

In practice, there are assessment types utilized, among them are written, field practice, observation and portfolio tst.

1) Written test instrument in form of questions

The assessment is performed by calculating correct answer of the available questions. The maximum score is 100 . It is obtained by calculating the score obtained which is divided by maximum score and multiplied by a hundred. There is guideline to determine the score, which is conversion guideline with scale 0 to 100 as follow:

Table 1. Score Conversion Guideline

\begin{tabular}{|c|c|c|}
\hline Score Conversion (Scale 0-100) & Predicate & Classification \\
\hline $81-100$ & A & SB (Very Good) \\
\hline $66-80$ & B & B (Good) \\
\hline $51-65$ & C & C (Moderate) \\
\hline $0-50$ & D & K (Less) \\
\hline
\end{tabular}

1) Work instrument inm form of assessment rubric. The following is role play assessment rubric:

Table 2. Example of Role Play Rubrics

\begin{tabular}{|l|l|l|l|l|l|}
\hline No & Criteria & $\begin{array}{l}\text { Very Good } \\
\mathbf{4}\end{array}$ & $\begin{array}{l}\text { Good } \\
\mathbf{3}\end{array}$ & $\begin{array}{l}\text { Moderate } \\
\mathbf{2}\end{array}$ & $\begin{array}{l}\text { Need } \\
\text { Guidance } \\
\mathbf{1}\end{array}$ \\
\hline 1 & Exspression & $\begin{array}{l}\text { Face mimics and } \\
\text { body movements } \\
\text { as the dialogue } \\
\text { consistently. } \\
\text { Gimmics }\end{array}$ & $\begin{array}{l}\text { Face mimics and } \\
\text { body movements } \\
\text { as the dialogue } \\
\text { but it is } \\
\text { inconsistent. }\end{array}$ & $\begin{array}{l}\text { Face mimics } \\
\text { and body } \\
\text { movements as } \\
\text { the dialogue }\end{array}$ & $\begin{array}{l}\text { Monotonous } \\
\text { without } \\
\text { expression. }\end{array}$ \\
\hline 2 & $\begin{array}{l}\text { Voice } \\
\text { Volume }\end{array}$ & $\begin{array}{l}\text { Heard in a whole } \\
\text { room. }\end{array}$ & $\begin{array}{l}\text { Heard in a half of } \\
\text { the room. }\end{array}$ & $\begin{array}{l}\text { Heard until } \\
\text { the front side } \\
\text { of the room. }\end{array}$ & $\begin{array}{l}\text { The voice is } \\
\text { very low or } \\
\text { cannot be } \\
\text { heard. }\end{array}$ \\
\hline
\end{tabular}

The score calculation is obtained by dividing the score numbers which are obtained by students with ideal score, furthermore it is multiplied by 100 . The information of score obtained by the students is the score obtained from criteria 1 and 2 . The ideal score is the multiplication of criteria numbers and the highest score. The evaluation instrument is in form of observation sheet.

\section{b. Attitude or Students' Character Assessment}

Attitudes and characters that will be developed in grade II are honest, discipline, responsible, polite, care, confidence, obey the rules, careful, affection, cooperation, respect etc. In order to achieve the character values, they perform various learning activities indirectly, beside, teachers are expected to assess certain character value achievement on students directly. The following steps become the consideration to do assessment.

1) Since time availability is lmited, thus in Semester 1 teachers are able to determine 2 or 3 of character values that will be developed and assessed directly. The character type that will be developed should be the school decisio. Although it does not cover possibility that there are 1 or 2 character values as the requirement in the class.

2) For example, accurate, self confidence and responsible will be developed in semester 2 .

3) Each character is made an indicator.

\footnotetext{
${ }^{19}$ Suharsimi Arikunto, Dasar-Dasar Evaluasi Pendidikan, Edisi Revisi, (Bandung: Bumi Aksara, 2010), p. 6.

${ }^{20}$ Suharsimi Arikunto, Dasar-Dasar..., p. 26.

${ }^{21}$ Kemendikbud RI, Bermain di Lingkunganku, Buku Tematik Terpadu Kurikulum 2013 Buku Guru SD/MI Kelas
} II, (Jakarta: Kemendikbud RI, 2014), p. vii.

DOI: 10.9790/0837-2205092337 $\quad$ www.iosrjournals.org $\quad 31 \mid$ Page


4) Assessment Instrument Development, for example observation sheet.

In outline, assessment involves three aspects: attitude, knowledge, and skill. Attitude assessment uses attitude scale, knowledge assessment uses test, and skill assessment uses field practice. The forms of conversational text skill assessment are:

a) Assessment Rubrics of Conversational text reading

\begin{tabular}{|c|l|l|l|l|l|}
\hline No & Criteria & \multicolumn{1}{|c|}{$\begin{array}{c}\text { Very Good } \\
\mathbf{4}\end{array}$} & \multicolumn{1}{|c|}{$\begin{array}{c}\text { Good } \\
\mathbf{3}\end{array}$} & \multicolumn{1}{c|}{$\begin{array}{c}\text { Moderate } \\
\mathbf{2}\end{array}$} & \multicolumn{1}{|c|}{$\begin{array}{c}\text { Need Guidance } \\
\mathbf{1}\end{array}$} \\
\hline 1 & $\begin{array}{l}\text { Text } \\
\text { readingc } \\
\text { skill. }\end{array}$ & $\begin{array}{l}\text { Students are } \\
\text { able to read all } \\
\text { text. }\end{array}$ & $\begin{array}{l}\text { Students are } \\
\text { able to read a } \\
\text { most of text } \\
\text { part. }\end{array}$ & $\begin{array}{l}\text { Students are } \\
\text { able to read a } \\
\text { half part of text. }\end{array}$ & $\begin{array}{l}\text { Students have not } \\
\text { been able to read } \\
\text { text. }\end{array}$ \\
\hline 2 & $\begin{array}{l}\text { Textual } \\
\text { understa } \\
\text { nding }\end{array}$ & $\begin{array}{l}\text { Able to } \\
\text { answer all } \\
\text { proposed } \\
\text { questions. }\end{array}$ & $\begin{array}{l}\text { Able to answer } \\
\text { a half or more of } \\
\text { proposed } \\
\text { questions. }\end{array}$ & $\begin{array}{l}\text { Able to answer } \\
\text { less than a half } \\
\text { part of text. }\end{array}$ & $\begin{array}{l}\text { Have not been } \\
\text { able to answer all } \\
\text { proposed } \\
\text { questions. }\end{array}$ \\
\hline
\end{tabular}

b) Assessment Rubrics Write Main Points of Playing Activity at Home Environment

\begin{tabular}{|c|l|l|l|l|l|}
\hline No & \multicolumn{1}{|c|}{ Criteria } & \multicolumn{1}{|c|}{$\begin{array}{c}\text { Very Good } \\
\mathbf{4}\end{array}$} & \multicolumn{1}{|c|}{$\begin{array}{c}\text { Good } \\
\mathbf{3}\end{array}$} & $\begin{array}{c}\text { Moderate } \\
\mathbf{2}\end{array}$ & $\begin{array}{c}\text { Need } \\
\text { Guidance 1 }\end{array}$ \\
\hline 1 & $\begin{array}{l}\text { Skill to write } \\
\text { main points }\end{array}$ & $\begin{array}{l}\text { Students are } \\
\text { able to write } \\
\text { main points. }\end{array}$ & $\begin{array}{l}\text { Students are } \\
\text { able to write } \\
\text { some of main } \\
\text { points. }\end{array}$ & $\begin{array}{l}\text { Students are } \\
\text { able to write a } \\
\text { few main } \\
\text { points. }\end{array}$ & $\begin{array}{l}\text { Students have } \\
\text { not been able } \\
\text { to write main } \\
\text { points. }\end{array}$ \\
\hline 2 & $\begin{array}{l}\text { Accuracy in } \\
\text { writing main } \\
\text { points. }\end{array}$ & $\begin{array}{l}\text { Students } \\
\text { accurately } \\
\text { write main } \\
\text { points. }\end{array}$ & $\begin{array}{l}\text { Students } \\
\text { sufficiently } \\
\text { write main } \\
\text { points. }\end{array}$ & $\begin{array}{l}\text { Students less } \\
\text { accurately } \\
\text { write main } \\
\text { points. }\end{array}$ & $\begin{array}{l}\text { Students have } \\
\text { not accurately } \\
\text { written main } \\
\text { points. }\end{array}$ \\
\hline 3 & $\begin{array}{l}\text { Accuracy in } \\
\text { writing main }\end{array}$ & $\begin{array}{l}\text { Students } \\
\text { accurate;y } \\
\text { prite main } \\
\text { points. }\end{array}$ & $\begin{array}{l}\text { Students } \\
\text { sufficiently } \\
\text { write }\end{array}$ & $\begin{array}{l}\text { Students less } \\
\text { accurately } \\
\text { write main } \\
\text { important } \\
\text { main points. }\end{array}$ & $\begin{array}{l}\text { Students have } \\
\text { not accurately } \\
\text { written main } \\
\text { points. }\end{array}$ \\
& points. & \multicolumn{2}{|l}{} \\
\hline
\end{tabular}

c) Assessment Rubrics of Making Expression Picture

\begin{tabular}{|c|l|l|l|l|l|}
\hline No & Criteria & \multicolumn{1}{|c|}{$\begin{array}{c}\text { Very Good } \\
\mathbf{4}\end{array}$} & \multicolumn{1}{|c|}{$\begin{array}{c}\text { Good } \\
\mathbf{3}\end{array}$} & $\begin{array}{c}\text { Moderate } \\
\mathbf{2}\end{array}$ & $\begin{array}{c}\text { Need } \\
\text { Guidance } \\
\mathbf{1}\end{array}$ \\
\hline 1 & $\begin{array}{l}\text { Picture } \\
\text { composition }\end{array}$ & $\begin{array}{l}\text { Students draw } \\
\text { a very balance } \\
\text { picture result } \\
\text { between the } \\
\text { right and left } \\
\text { side assisted } \\
\text { by teacher. }\end{array}$ & $\begin{array}{l}\text { Students draw a } \\
\text { balance picture } \\
\text { result between the } \\
\text { right and left side } \\
\text { assisted by teacher. }\end{array}$ & $\begin{array}{l}\text { Students draw a } \\
\text { sufficient } \\
\text { balance picture } \\
\text { result between } \\
\text { the right and left } \\
\text { side assisted by } \\
\text { teacher. }\end{array}$ & $\begin{array}{l}\text { Students are } \\
\text { able to draw } \\
\text { but the result } \\
\text { is imbalance } \\
\text { between the } \\
\text { right and left } \\
\text { side assisted } \\
\text { by techer. }\end{array}$ \\
\hline 2 & $\begin{array}{l}\text { Picture } \\
\text { Proportion. }\end{array}$ & $\begin{array}{l}\text { It is seen that } \\
\text { the picture } \\
\text { result has a } \\
\text { very } \\
\text { appropriate } \\
\text { proportion. }\end{array}$ & $\begin{array}{l}\text { It is seen that the } \\
\text { picture result has } \\
\text { sufficient } \\
\text { appropriate } \\
\text { proportion. }\end{array}$ & $\begin{array}{l}\text { It is seen that the } \\
\text { picture result has } \\
\text { appropriate } \\
\text { proportion. }\end{array}$ & $\begin{array}{l}\text { It is seen that } \\
\text { the picture } \\
\text { result has } \\
\text { inappropriate } \\
\text { proportion. }\end{array}$ \\
\hline
\end{tabular}


d)

\begin{tabular}{|c|c|c|c|c|c|}
\hline No & Criteria & $\begin{array}{c}\text { Very Good } \\
4\end{array}$ & $\begin{array}{c}\text { Good } \\
3\end{array}$ & $\begin{array}{c}\text { Moderate } \\
2\end{array}$ & $\begin{array}{c}\text { Need } \\
\text { Guidance } 1\end{array}$ \\
\hline 1 & $\begin{array}{l}\text { Relevancy } \\
\text { between } \\
\text { content and } \\
\text { title and } \\
\text { subtheme. }\end{array}$ & $\begin{array}{l}\text { All writing } \\
\text { content is } \\
\text { relevant to the } \\
\text { title or theme. }\end{array}$ & $\begin{array}{l}\text { Most of } \\
\text { writing } \\
\text { content is } \\
\text { relevant with } \\
\text { title or theme. }\end{array}$ & $\begin{array}{l}\text { Small part of } \\
\text { writing } \\
\text { content is } \\
\text { relevant with } \\
\text { title or theme. }\end{array}$ & $\begin{array}{l}\text { All writing } \\
\text { content has } \\
\text { not been } \\
\text { relevant with } \\
\text { title or theme. }\end{array}$ \\
\hline 2 & $\begin{array}{l}\text { Numbers of } \\
\text { words used. }\end{array}$ & $\begin{array}{l}50 \text { words or } \\
\text { more. }\end{array}$ & 35 to 49 words & $\begin{array}{l}15 \text { to } 34 \\
\text { words. }\end{array}$ & $\begin{array}{l}\text { Less than } 15 \\
\text { words }\end{array}$ \\
\hline 3 & $\begin{array}{l}\text { The use of } \\
\text { upright } \\
\text { letters. }\end{array}$ & $\begin{array}{l}\text { All contents use } \\
\text { clear, neat and } \\
\text { clean upright } \\
\text { letters. }\end{array}$ & $\begin{array}{l}\text { Most of the } \\
\text { contents use } \\
\text { clear, neat and } \\
\text { clean upright } \\
\text { letters. }\end{array}$ & $\begin{array}{l}\text { A small part } \\
\text { of contents use } \\
\text { clear, neat and } \\
\text { clean upright } \\
\text { letters. }\end{array}$ & $\begin{array}{l}\text { Do not use } \\
\text { clear, neat and } \\
\text { clean upright } \\
\text { letters. }\end{array}$ \\
\hline 4 & PSS Use & $\begin{array}{l}\text { All writings use } \\
\text { correct PSS. }\end{array}$ & $\begin{array}{l}\text { Most of } \\
\text { writings use } \\
\text { correct PSS. }\end{array}$ & $\begin{array}{l}\text { Small part of } \\
\text { writings use } \\
\text { correct PSS. }\end{array}$ & $\begin{array}{l}\text { Do not use } \\
\text { correct PSS. }\end{array}$ \\
\hline
\end{tabular}

e)

Assessment Rubrics of Reasoning which is concerning Truth Value of A Similarity

\begin{tabular}{|c|c|c|c|c|c|}
\hline No & Criteria & $\begin{array}{c}\text { Very Good } \\
4\end{array}$ & $\begin{array}{c}\text { Good } \\
3\end{array}$ & $\begin{array}{l}\text { Moderate } \\
2\end{array}$ & $\begin{array}{c}\text { Need Guidance } \\
1\end{array}$ \\
\hline 1 & $\begin{array}{l}\text { Accuracy in } \\
\text { expressed } \\
\text { reason. }\end{array}$ & $\begin{array}{l}\text { All reasons are } \\
\text { expressed } \\
\text { correctly by } \\
\text { students. }\end{array}$ & $\begin{array}{l}\text { Most of } \\
\text { reasons are } \\
\text { expressed } \\
\text { correctly by } \\
\text { students. }\end{array}$ & $\begin{array}{l}\text { Small part of } \\
\text { reasons are } \\
\text { shown } \\
\text { correctly by } \\
\text { students. }\end{array}$ & $\begin{array}{l}\text { Reasons are not } \\
\text { expressed } \\
\text { correctly by } \\
\text { students. }\end{array}$ \\
\hline 2 & $\begin{array}{l}\text { Voice } \\
\text { Volume }\end{array}$ & $\begin{array}{l}\text { Heard in all } \\
\text { parts of room. }\end{array}$ & $\begin{array}{l}\text { Heard in a half } \\
\text { part of room. }\end{array}$ & $\begin{array}{l}\text { Heart in only a } \\
\text { part of room. }\end{array}$ & $\begin{array}{l}\text { Voice are not } \\
\text { heard. }\end{array}$ \\
\hline 3 & $\begin{array}{l}\text { Students' } \\
\text { competence } \\
\text { in providing } \\
\text { similarity } \\
\text { and truth } \\
\text { value. }\end{array}$ & $\begin{array}{l}\text { Students are } \\
\text { able to provide } \\
\text { all reasons of } \\
\text { truth and } \\
\text { similarity value } \\
\text { correctly. }\end{array}$ & $\begin{array}{l}\text { Students are } \\
\text { able to provide } \\
\text { most reasons } \\
\text { of truth and } \\
\text { similarity } \\
\text { value } \\
\text { correctly. }\end{array}$ & $\begin{array}{l}\text { Students are } \\
\text { able to provide } \\
\text { small part of } \\
\text { reasons of } \\
\text { truth and } \\
\text { similarity } \\
\text { value } \\
\text { correctly. }\end{array}$ & $\begin{array}{l}\text { Students are not } \\
\text { able to provide } \\
\text { reason of truth } \\
\text { and similarity } \\
\text { value correctly. }\end{array}$ \\
\hline
\end{tabular}

\section{Reflection, Sorting, and Remedy}

Evaluating is also related to some things, amongt them are: reflection, sorting, and learning together with parents. One of points that become reflection materials is related to matters that should be a special attention, success note, and they that should be improved.

The next actitivities is remedial consideration. It is done in certain condition, for example in the learning contexts as follow"

1) If students have been able to find syllable that has not been known from mathematics concerning summation (1 syllable for right and left part of division) and provided reasons concerning a truth value of similarity, so they do additional questions given by teacher.

2) If students are able to draw expression, teachers give continued assignment to draw expression with different variations.

3) If students have mastered writing a narrative, teachers give additional assignment for them.

4) Teachers repeat activity of finding syllables that have ben known from mathematics sentence concerning summation (1 syllable for the right and left part of division) and give reason which is related to truth value of a similarity for students who have not understood it,

5) Teachers give assignment for students who have not been able to draw expressive picture.

6) Teachers give remedy for students who have not been able to write a narrative, 
7) Students discuss with parents on games which are often done at home. Then they ask parents' guidance to write neccessary things concerning the game.

8) Discuss the importance of unity attitude in games with parents. Also, things that should be done before, during and after playing at home environment, for example if they play foot ball at home and what the consequences are. After doing the assignment at home, then we clean the house.

\section{Thematic Learning Report}

Raport on thematic learning model will make descriptions of some competences covering spiritual, social and knowledge competences (some lesson content) and skill. ${ }^{22}$ There is score calculatiom in making a report because the score will be presented only in description, which means without numeric score. The guidelines of numeric score conversion becomes final score that can be seen in the following table:

\begin{tabular}{|c|c|c|c|c|c|}
\hline Modus & Predicate & Mean Score & Letter & Optimum Achievement & Letter \\
\hline 4.00 & VB (Very & $385-400$ & $\mathrm{~A}$ & $3.85-4.00$ & $\mathrm{~A}$ \\
& Good) & $3.51-3.84$ & $\mathrm{~A}-$ & $3.51-3.84$ & $\mathrm{~A}-$ \\
\hline \multirow{2}{*}{3.00} & G (Good) & $3.18-3.50$ & $\mathrm{~B}+$ & $3.18-3.50$ & $\mathrm{~B}+$ \\
& & $2.85-3.17$ & $\mathrm{~B}$ & $2.85-3.17$ & $\mathrm{~B}$ \\
& & $2.51-2.84$ & $\mathrm{~B}-$ & $2.51-2.84$ & $\mathrm{~B}-$ \\
\hline 2.00 & A (Average) & $2.18-2.50$ & $\mathrm{C}+$ & $2.18-2.50$ & $\mathrm{C}+$ \\
& & $1.85-2.17$ & $\mathrm{C}$ & $1.85-2.17$ & $\mathrm{C}$ \\
& & $1.51-1.84$ & $\mathrm{C}-$ & $1.51-1.84$ & $\mathrm{C}-$ \\
\hline 1.00 & L (Lack) & $1.18-1.50$ & $\mathrm{D}+$ & $1.18-1.50$ & $\mathrm{D}+$ \\
& & $1.00-1.17$ & $\mathrm{D}$ & $1.00-1.17$ & $\mathrm{D}$ \\
\hline
\end{tabular}

Based on the table above, teacher guardian makes a report. The scores presented are final score, attitude towards certain themes will be in form of tendency or score emerge (modus). Score that often emerges or which is known as modus has actually represented existing scores because the condition represents most scores or maximum frequency. ${ }^{23}$

Attitude score in raport will be in form of description, for example as follow: spiritual description: Ani is good in praying before she does activities, grateful behavior; still needs guidance on special aspect in praying. Ani has been very in devout aspect of praying on time; still needs grateful behavior lesson.

Social score description as sampled is as follow: Ani has been good in self-confidence and order; still needs guidance in cooperation aspect. Ani has been very good in disciplinary and politeness; she still needs guidance in orderliness. Knowledge score recapitulation can be explained as follow: score which emerges is average score of daily assessment result of each subtheme, Mid-Test and Scool Final Examination. Report on learning uses thematic model which utilizes report special application run in Microsoft Exel 2007 program.

\section{Weaknesses and Strenghts of Integrative Thematic Model Learning}

Thematic learning is a learning model which is packaged in curriculum 2013 framework. Thematic model is not really new, but the format becomes new when it is imlemented in curriculum 2013 framework. Therefore, it requires deeper review to organize it well. Some teachers complain about the difficulty of this model learning, as said by Achiayadi as one of classroom teachers at State I Primary School Godean. He says that this learning is difficult to implement in the class because low class has not been able to discuss. ${ }^{24}$ Discussion activity is one of material presented in curriculum 2013 thematic. The problem which emerges tend to be in the classroom mastery. According to Achiayadi, sometimes in the discussion, sixty percents of students are dazed and speechless. Classroom discussion is usually divided into groups. Each group has different members; it the group contains of students who have average intelligence, the discussion will be performed well. On the other hands, if group members do not have good skill, the communication or material mastery will not be achieved.

If such thing occurs, the learning becomes incomplete. The next policy done by teachers is remedy. ${ }^{25}$ It is different to discussion practice as performed in higher grade. Teachers do not find difficulty in thematic learning implementation with discussion method. However, there are some things that do not follow teachers'

${ }^{22}$ Kemendikbud, Kurikulum 2013 Kemendikbud Badan Pengembangan Sumber Daya Manusia Pendidikan Kebudayaan dan Penjaminan Mutu Pendidikan, (Jakarta: Pusat Pengembangan Pendidik 2015), p. 1.

${ }_{23}$ Anas Sudijono, Pengantar Statistik Pendidikan, (Jakarta: PT Rajawali Citra), p. 105.

${ }^{24}$ Interview with Achiayadi, Classroom teacher of III State Primary School I Sleman, Senin 26 September 2016

${ }^{25}$ Interview with Achiayadi, Classroom teacher of III State Primary School I Sleman, Kamis 29 September 2016 
guideline because of effectiveness consideration, such as some materials missed with consideration is not too significant towards competence increase, it is as presented teacher guidance of grade 5 that is higher grade. ${ }^{26}$

Material in thematic learning model is said as superficial ${ }^{27}$ so that teacher and students should be creative in digging another source, including books on KTSP curriculum that is still used to complete the lack of material details. It also becomes weakness points on thematic learning model. When using KTSP, material is reached in more details and gives sufficient information. On the other side, material thematic is too light and raises problem because of lack of material. When the material reaches certain difficulty level but cannot reach the point, it is said as less proportional.

When the material is less detail, teacher finds material from other sources. Furthermore the material is thematized, but it is only given as in the lesson approach. However, the teacher includes it inthe Lesson Plan, so that it is said that he/she returns to KTSP Curriculum.. ${ }^{28}$ It is also applied in the assessment of students' graduation or Final Examination. In Final Examination, 50\% of test questions base on the materials taught in KTSP Curriculum, while the rest is based on Curriculum 2015. Thus, teacher carries out additional lesson so that students are able to pass Final Examination. One of them is by giving try out or course taken from KTSP Curriculum material. ${ }^{29}$

\section{CONCLUSION}

Presenting material in thematic learning is not easy. It requires teachers' creativity. The intended creativity is teacher's competence to analyze lesson. Material analysis is started from school graduates competence standard, then core competence of each class and continued with competence standard analysis. Competence standard is elaborated using networks such as 5 lesson which includes Bahasa Indonesia, Mathematics, SBDP, Sport and Health Psysical Education and Civics Education. Furthermore it is included in learning scope. It determines subtheme which breakdowns books main theme. Learning scope desscribes which learinng activities done and competences developed. After dividing it using networks, it is continued with inicator mapping which is divided into five lessons. After learning indicator is formulated, subtheme is divided into six lessons, which are learning 1,2, etc. Learning 1 will be completed in one day, if the material has not been completed, it will completed on the next day. After conducting research, we can draw positive and negative sides. There are some researcher's point of views that can be considered as good suggestions for teacher or institution.

\section{For teacher}

Learning by using thematic model has difference from previous curriculum, such as less detail thematized material. This weakness should be seen by teacher as an opportunity to be more creative to develop materials by finding it from various sources. Learning sources are not only limited from teacher's or student's book, but from various media, for example internet sites, television, redio, social and cultural environment. Some teachers compalain the complicated learning using the model. However, by seeing it as a positive opportunity to improve teacher's competence. Thus the weakness becomes strenght and positive value for them. As a result, it has positive effect for learners or institution.

\section{For Institution}

For the institution, thematic model learning requires special skill to perform it well. Thus it requires special training so that the learning is structured well. Teacher's training which is facilitated by the instituion will give signficant contribution towards the institution development and improvement. Besides, teachers' coordination among different education istitution will ad insight on thematic implementation in each school. By knowing the processs variations or thematic learning result in different institution, it becomes suggestion for school to improve thematic learning so that it becomes fun.

\section{REFFERENCES}

[1]. Asrori, Imam dkk. Evaluasi Pembelajaran Bahasa Arab. Malang: Misykat 2012.

[2]. Anonim, Makalah, Unit 3 Desain Pembelajaran PAKEM, 22 Juni 2006.

[3]. Anonim, Standar Isi Madrasah Ibtidaiyah. Jakarta, Direktorat Jendral Pendidikan Islam Depag RI. 1996.

[4]. Anonim. UU RI No.9 Tahun 2009 Tentang Badan Hukum Pendidikan dan UU. RI No.20 Tahun 2003 Tentang Sistem Pendidikan Nasional. Jakarta: Asa Mandiri, 2009.

[5]. Arikunto, Suharsimi. Dasar-Dasar Evaluasi Pendidikan. Jakarta: Bumi Aksara, 1996.

[6]. __ _ Prosedur Penelitian Suatu Pendekatan Praktis. Jakarta: Bumi Aksara, 1998.

\footnotetext{
${ }^{26}$ Interview with Dwi Ismawati, Classroom teacher of V State Primary School I Sleman, Jumat 30 September 2016

${ }^{27}$ Interview with Yadi, Classroom teacher of V State Primary School I Sleman, Jumat 30 September 2016

${ }^{28}$ Interview with Dwi, Ismawati Classroom teacher of V State Primary School I Sleman, Jumat 30 September 2016

${ }^{29}$ Interview with Yadi, Classroom teacher of V State Primary School I Sleman, Jumat 30 September 2016 
[7]. Babage, R., R. Byers dan H.Redding. Approach to Teaching and Learning. London: Paul Chapman Publishing ltd, 1994.

[8]. Burhanudin. Analisis Administrasi Manajemen dan Kepemimpinan Pendidikan. Jakarta: Bina Aksara, 1994.

[9]. Bush, T., M. Coleman. Leadership and Strategi Manajemen in Education. London: Paul Chapman Publishing Ltd, 2004.

[10]. Departemen Pendidikan Nasional, Pedoman Untuk Pengembangan Silabus Berbasis Kompetensi. Jakarta: Kemendiknas, 2004.

[11]. Dwi Tyas Utami. Buku Teks Tematik Terpadu Tema Diriku Untuk SD/MI Kelas I, Bandung: Erlangga, 2013.

[12]. Djiwandono, Sri Esti Wuryani. Upaya Peningkatan Pembelajaran Bahasa Indonesia SMPN 2 Pundong Bantul. Tesis Universitas Negeri Yogyakarta, 2007 Tidak diterbitkan.

[13]. Durori, Muhammad. Konsep Penerapan Model Belajar Mandiri Dalam Pembelajaran Aktif Kreatif Efektif dan Menyenangkan (PAKEM). Banyumas: Mitramas, 2007.

[14]. Eyes H, \& F.Grey. Classroom Manajemen. London: David Fulton Publisher, 1988.

[15]. Hadi, Sutrisno. Metodologi Riset I. Yogakarta: Fakutas Psikologi UGM, 1998.

[16]. Hernowo. Menjadi Guru yang Mampu Mau dan Mampu Mengajar Secara Menyenangkan. Bandung: Mizan, 2006.

[17]. Indrawijaya, Adam Ibrahim. Perilaku Organisasi. Bandung: CV.Sinar Baru, 1983.

[18]. Lie, Anita. Cooperative Learning, Mempraktikkan Cooperative Learning di Ruang-Ruang Kelas. Jakarta: Grasindo, 2008.

[19]. Kemendikbud RI. Bermain di Lingkunganku, Buku Tematik Terpadu Kurikulum 2013 Buku Guru SD/MI Kelas II. Jakarta: Kemendikbud RI, 2014.

[20]. Kemendikbud RI, Tema I Diriku, Buku Tematik Terpadu Kurikulum 2013, Buku Guru SD/MI Kelas I. Jakarta: Kemendikbud RI, 2015.

[21]. Kemendikbud RI, Tema 2 Selalu Berhamat Energi, Buku Guru SD/MI Kelas IV, Cet. 2. Jakarta: Kemendikbur RI, 2013.

[22]. Kemendikbud RI. Tema 2 Peristiwa Dalam Kehidupan, Buku Guru SD/MI Kelas VI, Cet 1. Jakarta: Kemendikbud RI, 2014.

[23]. Kemendikbud RI. Tema 2 Peristiwa Dalam Kehidupan, Buku Tematik Terpadu Kurikulum 2013, Buku Guru SD/MI Kelas V. Jakarta: Kemendikbud RI, 2014.

[24]. Khaeruddin, dan Mahfud Junaedi. Kurikulum Tingkat Satuan Pendidikan: Konsep dan Implementasi di Madrasah. Yogyakarta: Pilar Media, 2007.

[25]. Majid, Abdul. Perencanaan Pembelajaran, Mengembangkan Standar Kompetensi Guru. Bandung: Remaja Rosdakarya, 2006.

[26]. Miles, Michael Bray Huberman, Qualitative Data Analysis. London: New Delhi Sage Publicaton Internal and Profesional Pulisher, 1995.

[27]. Pemanasari. Peran Penilaian Daya Tarik Fisik Status Sosial Ekonomi Orang Tuan dan Prestasi Belajar Terhadap Penolakan Diri Remaja. Yogyakarta: Fakultas Psikologi UGM, 1995.

[28]. Pudjiadi, Anna. Sains Teknologi Masyarakat, Model Pembelajaran Kontekstual Bermuatan Nilai. Bandung: Rosdakarya: 2005.

[29]. Pusat Kurikulum, Model Pengembangan Kurikulum Tingkat Satuan Pendidikan. Jakarta:Balitbang Depdiknas, 2006.

[30]. Rahim, Husni. Arah Baru Pendidikan di Indonedia. Jakarta: Logos, 2001.

[31]. Safaria, Triantoro. Creative Quotion, Panduan Mencetak Anak Super Kreatif. Yogyakarta: Platinum, 2005.

[32]. Suharsimi Arikunto, Dasar-Dasar Evaluasi Pendidikan, Edisi Revisi. Bandung: Bumi Aksara, 2010.

[33]. Sagala, Saiful. Konsep dan Makna Pembelajaran. Bandung: Alvabeta, 2000.

[34]. Santoso, Puji. Materi dan Pembelajaran Tematik Terpadu Sekolah Dasar, Jakarta: UT, 2007.

[35]. Sayekti, Ida. Manajemen Pembelajaran Bahasa Arab Ma'had Ali UMY. Tesis UIN Sunan Kalijaga, 2007 Tidak diterbitkan.

[36]. Subroto, B.Suryo. Manajemen Pendidikan di Sekolah. Jakarta: Rinekacipta, 2004.

[37]. Sudjana, Nana. Penilaian Proses Hasil Belajar Mengajar. Bandung: Rosdakarya, 1996.

[38]. Sumardi, Imam. Dasar-Dasar Administrasi Pendidikan. Jakarta: Depdikbud, 1998.

[39]. Surakhmad, Winarno. Strategi Pembelajaran. Makalah. Disampaikan Pada Diklat Matematika di SD dan SLTP Pada 25 Agustus 2003. Yogyakarta: PPG Matematika.

[40]. Swastiwi, Sri Hesti, Upaya Peningkatan Tematik Terpadu di SMPN 2 Pundong Bantul. Tesis UNY, 2007 Tidak diterbitkan. 
[41]. Tim Penyusun Kamus, Pusat Pembinaan dan Pengembangan Bahasa Departemen Pendidikan dan Kebudayaan, Jakarta: Balai Pustaka, 1994.

[42]. Udayana, Yusuf. Kepemimpinan Dalam Organisasi. Jakarta: Prenhallindo, 1994.

[43]. Usman, Moh.Uzer. Menjadi Guru Profesional, Bandung: Remaja Rosdakarya, 1995.

[44]. http//www.kr.co.id diakses 1 Mei 2016.

[45]. http//www.iastate.edu diakses 2 Mei 2016.

[46]. Materi pelatihan model pembelajaran tematik terpadu Kementrian Pendidikan dan Kebudayaan, 2013. 